\begin{tabular}{|c|c|c|c|}
\hline \multirow{2}{*}{$\begin{array}{r}\text { Case Reports in } \\
\text { Gastroenterology }\end{array}$} & \multicolumn{2}{|c|}{ Case Rep Gastroenterol 2015;9:160-164 } & \multirow[b]{2}{*}{$\begin{array}{l}\text { Karger } \\
\text { Open'access }\end{array}$} \\
\hline & $\begin{array}{l}\text { DOI: } 10.1159 / 000430493 \\
\text { Publisnea onine. TVIay 13, } 2015\end{array}$ & $\begin{array}{l}\text { (C) } 2015 \text { S. Karger AG, Basel } \\
1662-0631 / 15 / 0092-0160 \$ 39.50 / 0 \\
\text { www.karger.com/crg }\end{array}$ & \\
\hline & \multicolumn{2}{|c|}{$\begin{array}{l}\text { This is an Open Access article licensed under the terms of the Creative Commons } \\
\text { Attribution-NonCommercial } 3.0 \text { Unported license (CC BY-NC) (www.karger.com/OA } \\
\text { license), applicable to the online version of the article only. Distribution permitted for non } \\
\text { commercial purposes only. }\end{array}$} & \\
\hline
\end{tabular}

\title{
Achalasia in a Patient with Polyglandular Autoimmune Syndrome Type II
}

\author{
Bashar S. Amr ${ }^{a}$ Chaitanya Mamillapalli ${ }^{b}$ \\ Departments of ${ }^{a}$ Internal Medicine and ${ }^{b}$ Endocrinology, Southern Illinois University, \\ Springfield, IIl., USA
}

\section{Key Words}

Achalasia $\cdot$ Polyglandular autoimmune syndrome $\cdot$ Addison's disease

\begin{abstract}
Achalasia is a rare disease characterized by aperistalsis of the esophageal body and failure of the lower esophageal sphincter to relax. The etiology of this disease remains unknown. Polyglandular autoimmune syndrome type II is a well-identified disease characterized by the occurrence of autoimmune Addison's disease in combination with autoimmune thyroid disease and/or type 1 diabetes mellitus. We report a case that suggests autoimmunity and immunogenicity as a probable contributing factor for association of these two rare disorders.
\end{abstract}

(c) 2015 S. Karger AG, Basel

\section{Introduction}

Autoimmune disorders are often found in association with other endocrine and/or nonendocrine diseases. When two or more glandular autoimmune-mediated diseases coexist in a patient, it is termed as polyglandular autoimmune syndrome (PAS). A variety of clusters of autoimmune-mediated endocrinopathies may exist, each giving rise to a different type of PAS. PAS type II is characterized by the obligatory occurrence of autoimmune Addison's disease in combination with autoimmune thyroid disease and/or type 1 diabetes mellitus [1]. Primary hypogonadism, myasthenia gravis and celiac disease also are commonly observed in this syndrome. PAS type II has a prevalence of 1 in 20,000, occurs more frequently in women with a 1:3 male:female ratio and has a peak incidence at ages 20-60 years. On the other hand, achalasia is a rare disease characterized by aperistalsis of the esophageal body

KARGER 125/s $\quad \begin{aligned} & \text { Bashar S. Amr } \\ & \text { P.O. Box 19636 } \\ & \text { Springfield, IL 62794-9636 (USA) } \\ & \text { E-Mail bamr@siumed.edu }\end{aligned}$


Amr and Mamillapalli: Achalasia in a Patient with Polyglandular Autoimmune Syndrome Type II

and failure of the lower esophageal sphincter to relax. Achalasia has a prevalence of 10 in 100,000 , occurs equally in men and women and has a peak incidence at ages 30-60 years. Though viral infections, neuronal degradation, genetic inheritance and autoimmune disease have all been proposed causes of this disease, the etiology of this entity remains unknown [2]. Dysphagia and vomiting are common symptoms in achalasia due to the lower esophageal sphincter failure to relax. These symptoms are also common in PAS type II as a result of the metabolic disturbances and myopathy associated with untreated Addison's disease. In patients with PAS type II, these symptoms resolve with hormone replacement. Patients with achalasia, on the other hand, require a more invasive therapy, pneumatic dilatation of the esophagus or surgical myotomy, to improve such symptoms. We report a patient with PAS type II who presented with idiopathic achalasia and correlate our case with the suggested theory of an autoimmune etiology of achalasia.

\section{Case Description}

A 53-year-old man with no significant past medical history presented with progressive symptoms of nausea, loss of appetite, decreased food intake, insomnia, generalized fatigue, muscle weakness, dizziness and joint pain, along with a 30-pound weight loss over the preceding 30 days (from 220 to $190 \mathrm{lbs}$, a 13.6\% weight loss). He also complained of chronic difficulty in swallowing for the past 7 years, particularly liquids, that had slowly progressed to involve solids. On physical examination he was found to have a temperature of $34.9^{\circ} \mathrm{C}$, a heart rate of $108 \mathrm{bpm}$ and a blood pressure of $88 / 60 \mathrm{~mm} \mathrm{Hg}$. Though he appeared tired and fatigued, he was not in any acute distress. He had a dry oral mucosa and a darkened tanned appearance of his skin. Laboratory blood tests revealed significantly elevated TSH $(74 \mu \mathrm{IU} / \mathrm{ml})$, low free T4 levels $(0.6 \mathrm{ng} / \mathrm{dl})$ and low cortisol levels $(<1.0 \mu \mathrm{g} / \mathrm{dl})$, which did not rise after cosyntropin stimulation testing. His serum adrenocorticotropic hormone level was also elevated $(733 \mathrm{pg} / \mathrm{ml})$, which explained the patient's hyperpigmentation. He was also found to have positive anti-21-hydroxylase antibodies and anti-thyroid peroxidase antibodies. Intravenous fluid resuscitation quickly increased blood pressure to normal values. The patient was then started on replacement levothyroxine and hydrocortisone. He presented 4 weeks later with worsening dysphagia symptoms, which were initially thought to be due to adrenal insufficiency. A barium esophagogram revealed marked luminal narrowing at the gastroesophageal junction with bird beak configuration, consistent with achalasia (fig. 1). Manometry (fig. 2) and esophagogastroduodenoscopy studies (fig. 3) further confirmed the diagnosis of achalasia. Consequently, the patient underwent laparoscopic Heller myotomy. At 1-year follow up, he was in good health on continued steroid and thyroxin replacement.

\section{Discussion}

Our patient presented with autoimmune adrenal insufficiency and hypothyroidism, proven by positive anti-21-hydroxylase antibodies and anti-thyroid peroxidase antibodies, classifying him as PAS type II. One other case of PAS type II associated with megaesophagus has been reported in a human [3], and similar to our patient that case had positive adrenal and thyroid autoantibodies. However, our patient had both manometry and barium esophagogram studies consistent with achalasia, while manometry studies in the previously reported case were inconsistent with achalasia. Furthermore, the association of achalasia and 
Amr and Mamillapalli: Achalasia in a Patient with Polyglandular Autoimmune Syndrome Type II

autoimmune adrenal disease has been reported in dogs [4,5], thus making it plausible that these rare disorders in our patient could be connected.

Conceivable pathologies which would cause combined esophageal motility disorders and hypoadrenalism include amyloidosis, malignant infiltration of the esophagus and adrenal gland, adrenoleukodystrophy and Allgrove syndrome [3]. In our patient, histology of the esophageal biopsy specimens had excluded amyloidosis and malignancy. Allgrove syndrome (AAA syndrome) comprised hypoadrenalism, alacrima and achalasia. Anti-adrenal antibodies are negative in this syndrome and adrenal insufficiency is secondary to adrenocorticotropic hormone resistance causing isolated hypocortisolism with an intact renin-angiotensin system. Our patient had autoimmune hypoadrenalism affecting both the cortisol and aldosterone axes, which strongly argues against this diagnosis. While adrenoleukodystrophy of adult onset can be considered, absence of other neurological manifestations such as ataxia, muscle stiffness or peripheral neuropathy rules out this diagnosis.

We suggest autoimmunity and immunogenicity as a probable contributing factor for association of these two rare disorders. PAS type II is a well-identified entity with susceptibility genes, including HLA genes, the cytotoxic $\mathrm{T}$ lymphocyte antigen gene and the protein tyrosine phosphatase nonreceptor type 22 gene on chromosomes 6, 2 and 1, respectively [6]. These genes are known to increase the risk of developing autoimmune disorders without being causative. Of the HLA genes, DR3 and DR4 antigens are associated with PAS type II [3]. Furthermore, Addison's disease is a complex genetic disorder with a specific HLA-DR and HLA-DQ genotype that allots high risk.

Idiopathic achalasia is characterized by destruction of myenteric inhibitory neurons to the lower esophageal sphincter. The initiating cause of this destruction is still unknown. Although several studies have suggested a possible association between viral infections and achalasia [7-9], a clear causal relationship has not been established. On the other hand, autoimmune etiology of achalasia is supported by (1) the presence of circulating autoantibodies against the myenteric plexus, (2) presence of inflammatory $T$ cell infiltration in the myenteric plexus and (3) increased prevalence of HLA class II antigens [10]. Class II HLA antigens, including DQw1, DQA1*0103, DQB1*0603 and DQA1*0103-DQB1*0603 heterodimer, were more prevalent in the achalasia population as compared to controls. Although this HLA association also suggests immunogenic predisposition for the development of idiopathic achalasia, its specificity is limited and is causality is still unproven, as it may represent a nonspecific reaction to the disease process.

Five autoimmune diseases (type 1 diabetes mellitus, hypothyroidism, Sjögren's syndrome, systemic lupus erythematosus and uveitis) have been shown in a study to be more prevalent in achalasia patients than in the general population [11]. Though this association in not sufficient to define achalasia as an autoimmune disease, it raises suspicion and urges further research into autoimmune etiologies of achalasia. Current evidence suggests that the initial insult to the esophagus, perhaps a viral infection or some other environmental factor, results in myenteric plexus inflammation that leads to an autoimmune response in a susceptible population that may be genetically predisposed. Our patient's presentation of PAS type II with achalasia supports the theory of an autoimmune etiology.

\section{Disclosure Statement}

The authors declare that they have no conflicts of interest. 


\section{Case Reports in
Gastroenterology}

\begin{tabular}{l|l}
\hline Case Rep Gastroenterol 2015;9:160-164 \\
\hline DOI: 10.1159/000430493 & $\begin{array}{l}\text { C 2015 S. Karger AG, Basel } \\
\text { www.karger.com/crg }\end{array}$ \\
\hline
\end{tabular}

Amr and Mamillapalli: Achalasia in a Patient with Polyglandular Autoimmune Syndrome Type II

\section{References}

1 Kahaly GJ: Polyglandular autoimmune syndromes. Eur J Endocrinol 2009;161:11-20.

-2 Vaezi MF, Pandolfino JE, Vela MF: ACG clinical guideline: diagnosis and management of achalasia. Am J Gastroenterol 2013;108:1238-1249.

-3 Fritzen R, Bornstein SR, Scherbaum WA: Megaoesophagus in a patient with autoimmune polyglandular syndrome type II. Clin Endocrinol (Oxf) 1996;45:493-498.

-4 Bartges JW, Nielson DL: Reversible megaesophagus associated with atypical primary hypoadrenocorticism in a dog. J Am Vet Med Assoc 1992;201:889-891.

5 Bowen D, Schaer M, Riley W: Autoimmune polyglandular syndrome in a dog: a case report. J Am Anim Hosp Assoc 1986;22:649-654.

6 Eisenbarth GS, Gottlieb PA: Autoimmune polyendocrine syndromes. N Engl J Med 2004;350:2068-2079.

-7 Firouzi M, Keshavarzian A: Guillain-Barre syndrome and achalasia: two manifestations of a viral disease or coincidental association? Am J Gastroenterol 1994;89:1585-1587.

8 Dantas RO, Meneghelli UG: Achalasia occurring years after acute poliomyelitis. Arq Gastroenterol 1993;30: 58-61.

-9 Castex F, Guillemot F, Talbodec N, Colombel JF, Paris JC, Cortot A: Association of an attack of varicella and an achalasia. Am J Gastroenterol 1995;90:1188-1189.

10 Park W, Vaezi MF: Etiology and pathogenesis of achalasia: the current understanding. Am J Gastroenterol 2005;100:1404-1414.

11 Booy JD, Takata J, Tomlinson G, Urbach DR: The prevalence of autoimmune disease in patients with esophageal achalasia. Dis Esophagus 2012;25:209-213.

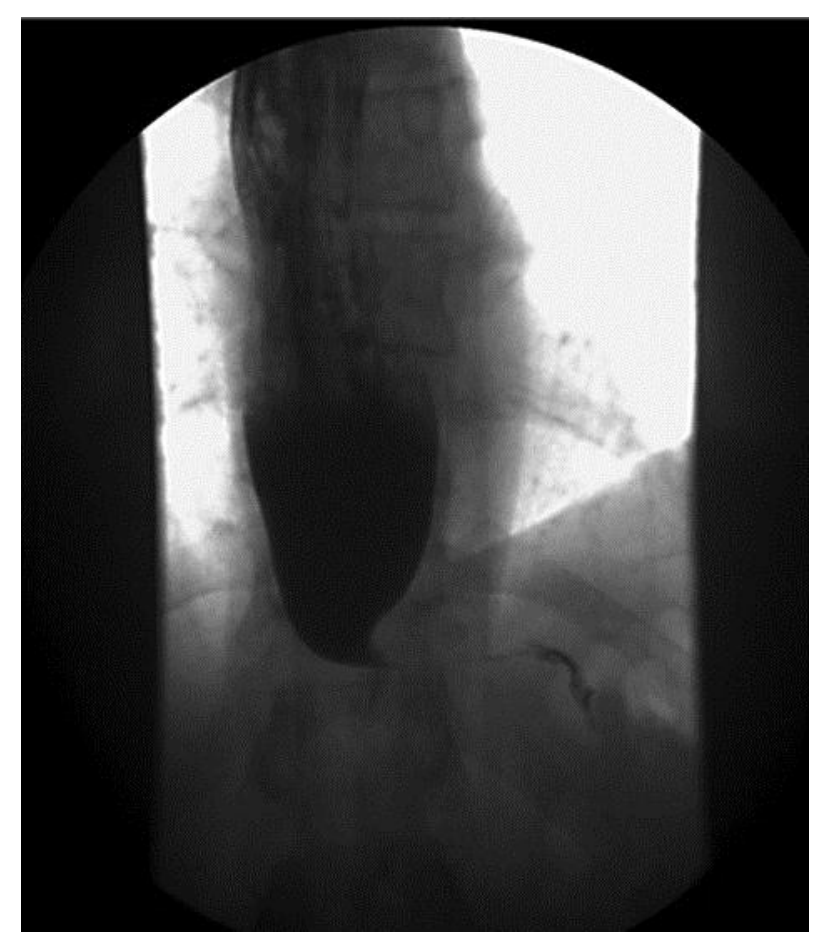

Fig. 1. Barium esophagogram showing marked luminal narrowing at the gastroesophageal junction with bird beak configuration, consistent with achalasia. 


\begin{tabular}{|c|c|c|}
\hline \multirow{3}{*}{$\begin{array}{r}\text { Case Reports in } \\
\text { Gastroenterology }\end{array}$} & \multirow{2}{*}{\multicolumn{2}{|c|}{ Case Rep Gastroenterol 2015;9:160-164 }} \\
\hline & & \\
\hline & DOI: $10.1159 / 000430493$ & $\begin{array}{l}\text { (c) } 2015 \text { S. Karger AG, Basel } \\
\text { www.karger.com/crg }\end{array}$ \\
\hline
\end{tabular}

Amr and Mamillapalli: Achalasia in a Patient with Polyglandular Autoimmune Syndrome Type II

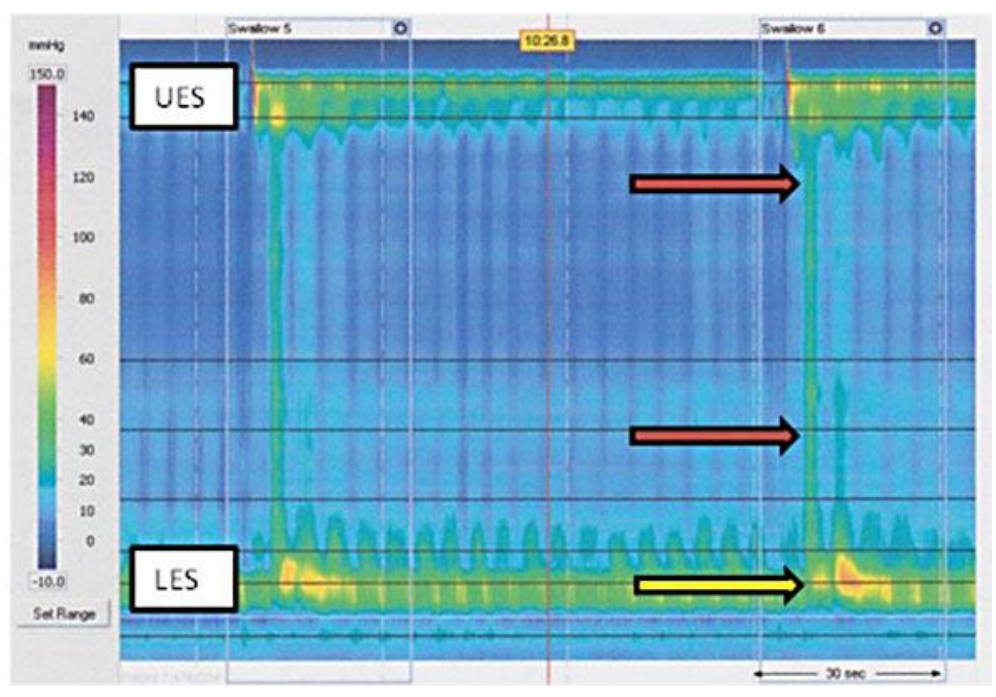

Fig. 2. High-resolution manometry revealing isobaric pressurization of the esophagus (red arrows) and poor lower esophageal sphincter relaxation (yellow arrow) compatible with type 2 achalasia. UES = Upper esophageal sphincter; LES = lower esophageal sphincter.

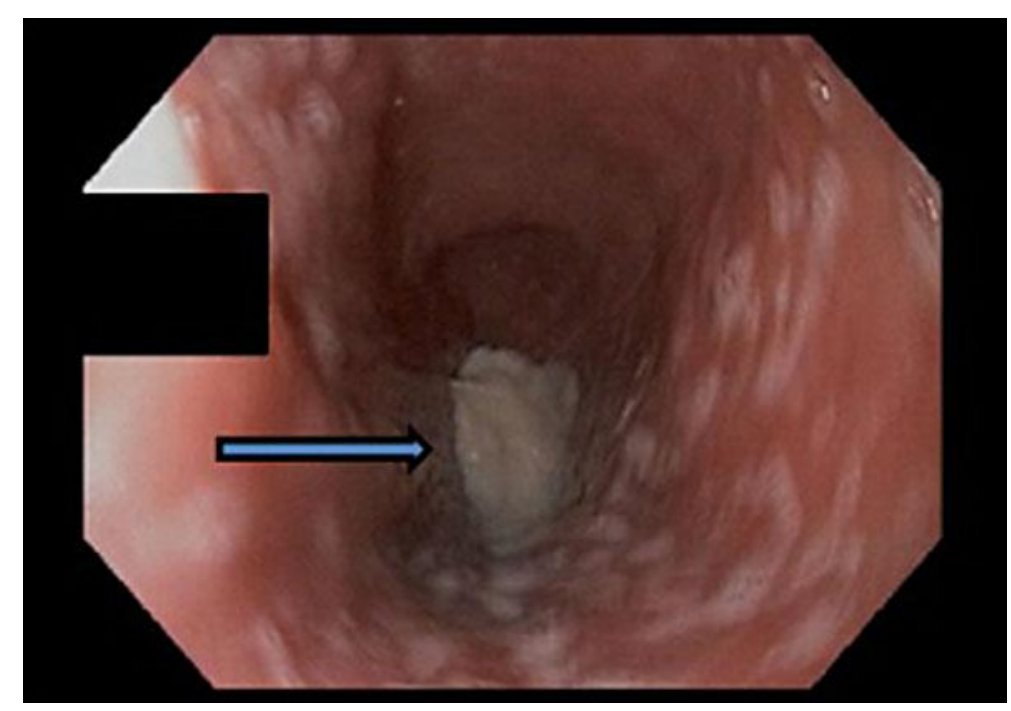

Fig. 3. Esophagogastroduodenoscopy revealing a dilated esophagus with retained barium (arrow). 